\title{
Telecommunications Reform in Samoa: The Introduction of Competition Law
}

\author{
Preliminary Findings from the Telecommunications Project \\ [ Bridget Crichton and Seve Tuipe'a Aloimaina Dr Folototo Seve ]
}

\begin{abstract}
Legislative and regulatory reforms in the telecommunications sector of Pacific Small Island Developing States ("SIDS") stands out from the wider Asia Pacific region. Samoa was the first of the Pacific SIDS to undergo telecommunications reform. With the enactment of Samoa's first Competition and Consumer Act (2016) ("the Act"), this article presents our preliminary findings from initial evidence exploring the interface between competition law and telecommunications reform in Samoa, following commencement of the Act in 2017, effectively repealing the Fair Trading Act 1998 and the Consumer Information Act 1989. It also seeks to understand the effective approaches to help redress regulatory and legislative compliance issues in the telecommunications sector. Key lessons from this research will be pivotal for the Telecommunications and Competition law makers in both Samoa and the Pacific SIDS. Research in this area will further address this gap in the literature and present credible evidence to build up a knowledge base about the role of competition law in Samoa telecommunications reform whilst contributing to the discourse of competition law and telecommunications reform in the Pacific SIDS region.
\end{abstract}

Keywords - Competition, law, regulation and telecommunication.

\section{Introduction}

Samoa is characterized as a "high vulnerability" nation recognised by key bottlenecks to development in the Pacific SIDS economies due to the lack of economic diversification, high susceptibility to internet hacking [1], but more specifically, isolation, geographical remoteness, susceptibility to natural disasters. Such characteristics have yielded further opportunities to revise regulatory intervention in dealing with the lack of capacity building support and the associated infrastructure investments within the Pacific landscapes.

Bridget Crichton, Commercial Law

Faculty of Business and Entrepreneurship

National University of Samoa

Samoa

Seve Tuipe'a Aloimaina Dr Folototo Seve, Dean

Faculty of Business and Entrepreneurship

National University of Samoa

Samoa
The smallness literature (i.e., SIDS-focused) suggests that the natural disadvantages hinders the development prospects of the SIDS [1]:34]. It is also another important control variable for telecommunications reform and consistently found to influence strongly and positively on the performance of the telecommunications sector [2]. Competition is therefore the most influential policy reform and also the most appropriate indicator for telecommunications regulatory reform in the Pacific SIDS [1]: $184-5$ ] while privatization seems to be less forthcoming. Other socio-political factors include corruption and bribery [1]: $184-5]$.

The motives behind the push by Pacific SIDS for telecommunications reform vary case by case; however, two factors emerge as common to all reforming Pacific SIDS case studies are their smallness and isolation. Also, the push for telecommunications regulatory reform to promote infrastructural development, as a means of promoting economic development and connecting isolated islands [1] :47]. The Government of Samoa ("GoS") support for the introduction of competition in the mobile market in its attempt to achieve universal access and establishing a competitive market was met with issues on account of Samoa's vulnerable characteristics including its smallness and isolation.

The entry of Digicel into Samoa in 2006 revolutionized the face of telecommunications in the Pacific SIDS region. Prior to 2006, Telecom Samoa Cellular Ltd ("TSC") had exclusive rights to the mobile segment [1]: 67]. Once Digicel was granted a licence in April 2006, a State Owned Enterprise ("SOE") and fixed-line operator known as SamoaTel launched its "GoMobile" campaign two months later [3], [4]. As a result, competition led to lower prices of phones and internet access and helped ignite small business development and growth across the Pacific [5]. In a span of less than one year, penetration went from $18 \%$ to $57 \%$ and growing [6], [4], [5]. The level of area coverage for mobile telephony in the country went from under $40 \%$ to $99 \%$ and prices dropped by more than $50 \%$ for both local and international calls [3].

Digicel acquired 90 per cent ownership of TSC effectively inheriting its licence and entitlements with the remaining 10 per cent acquired by the government owned Computer Services Ltd. ("CSL") [7]. This marked the end of a GoS 10 year exclusivity license granted in 1997 which effectively culminated in a joint venture between Telecommunications New Zealand ("TCNZ") and GOS. This was often labelled as the "bad contract" case. The low quality of TCNZ's mobile network infrastructure was a direct result of the five-to-six year delay in the introduction of modern mobile services in Samoa [4], [6], [3] which became a lesson for future Pacific SIDS telecommunications to avoid and GoS recognition of the significance of introducing a competitive framework and improving the 
provision of quality of telecommunications services in Samoa [4] : 237].

With the legislative support of Samoa's first Telecommunications Act 2005, it introduced the principle of competition into the Telecommunications sector and led to the establishment of the Office of the Regulator (refer to Table 1). Effectively, instrumental in activating market liberalisation into the Information and Communications Technology ("ICT").

TABLE I. SAMOA: TELECOMMUNICATIONS AND COMPETITION SNAPSHOT

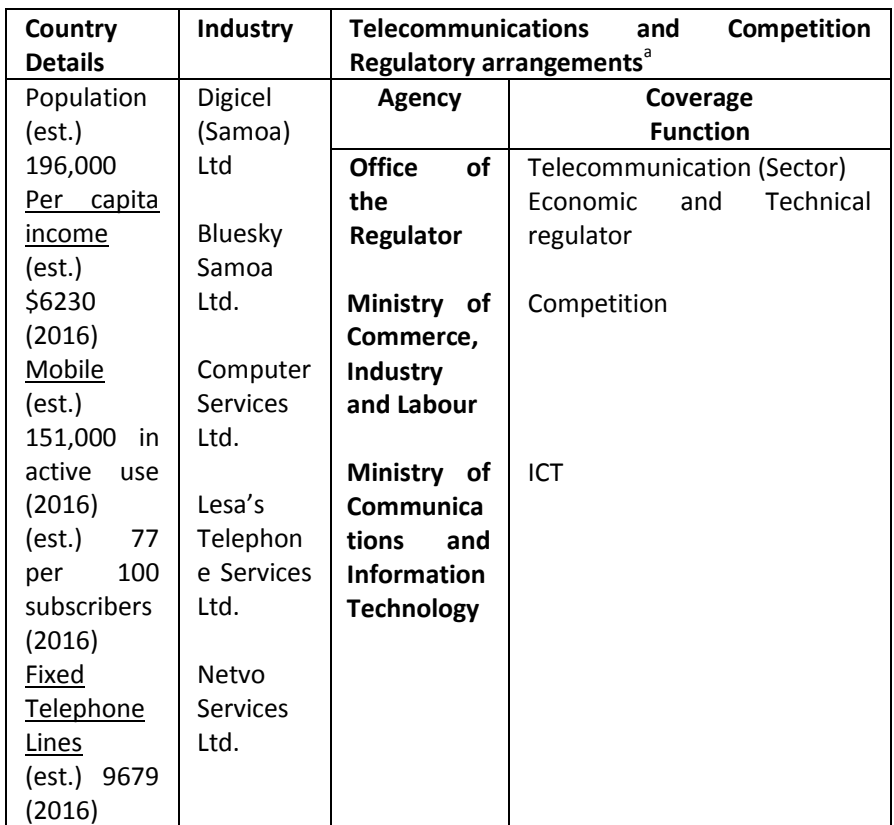

a. Source: Office of the Regulator 2016; Samoa Bureau of Statistics 2016; UNDP data on Samoa 2014; World Bank: Data 2018.

\section{Understanding the Telecommunications and Competition legislative context}

The telecommunications sector in Samoa has expanded as a result of privatization and increased competition. Against this backdrop, the MCIT National ICT Policy 20122017 defines ICT as "the convergence of data processing and telecommunications" [8]: 5]. ICT in Samoa is defined as comprising: telephony, broadcast media and all the equipment, processes and systems that are used to create, store, manage and share information. It encompasses analogue technologies, such as radio and television broadcasts, and digital technologies, such as mobile telecommunications and the internet [8]. This is particularly important in the current scope of the research as ICT development goals overlap with telecommunications services in Samoa. The Strategy for the Development of Samoa ("SDS") and the National ICT Policy also confines the telecommunications sector under the umbrella of ICT development goals. More specifically, the SDS (2005-2007 and 2008-2012) positioned telecommunications as a priority area in the Private sector. However, the recent SDS (20122016) and (2016/17 - 2019/20) now positions the telecommunications sector under the Infrastructure sector [9].
Therefore, the parameters of this research is confined to telecommunication services within the infrastructure sector of Samoa, specific to competition laws and policies governing telecommunications services [6]. Understanding the national status of telecommunications regulations in Samoa, for the purpose of this research, is inextricably linked to Competition law and policy. It requires an assessment of its existing policies, feasibility reports, interviews with key advisors in the telecommunications sector and an audit of its current telecommunications and competition law activities.

Our preliminary analysis is supported by grey literature, laws and survey data collected from our surveys and key interview informants, ranging from executives at the top Internet Service Providers, Academics and employees involved in both the ICT and telecommunications sectors.

Given the small sample from our preliminary findings thus far, it is important to note that this data is representative of the portion of the sector responsible for driving competition and telecommunications laws in Samoa [10]. Delays in information requests also highlights the longstanding issues of data collection in Samoa and the lack of legislative infrastructure such as an Official Information law or Freedom of Information law to ensure adequate governance in the exchange of information between public organisations, the public and researchers.

\section{A. Role of Competition in telecommunications}

He, Lim \& Wong [11] examine competitive dynamics in the telecommunications mobile market and posit that while incumbent firms possessing complementary assets and strong appropriability are typically in a formidable position, new innovative entrants can leverage complementary assets to enter along a new technological trajectory and then develop appropriability. In a dynamic industry such as telecommunications, it is difficult to consistently determine and enforce appropriate regulatory responses that promote competition and innovation [12].

Part 3 of the new Act covers the provision on competition rules to: prohibit abuse of market power by businesses that possess market power, prohibit anticompetitive agreements, bid-riggings between businesses. Including mergers that would substantially lessen competition. One of the important objectives of the Act is the establishment of the Competition and Consumer Commission ("Commission") and providing for its function. As provided in the Act, the Commission is to administer and enforce competition rules to safeguard consusmer protection. A variety of enforcement measures are made available to the Commission under Part 7 of the Act, such as a warning notice (s 117), enforceable undertakings (s 118), cease and desist notices (s 119), pecuniary penalties (s 124), orders to pay costs (s 126) and the like. The establishment of the Commission (s 6 under Part 2 of the Act) will alleviate common issues concerning businesses in order to allow for fair competition between businesses throughout Samoa. However, during the consultation stage, submissions noted that the Act be the Principal Act for all regulations and rules pertaining to competition and 
Proc. of The Eighth Intl. Conf. On Advances in Applied Science and Environmental Technology - ASET 2018 Copyright (C) Institute of Research Engineers and Doctors, USA. All rights reserved.

ISBN: 978-1-63248-155-9 doi: 10.15224/978-1-63248-155-9-31

consumers to also include the broadcasting and telecommunication sectors. It was resolved that regulations pertaining to competition and consumers in relation to broadcasting and telecommunication matters would still be monitored by the Regulator of Samoa.

Historically, the telecommunications context in Samoa in 2006, set the tone for competition as international phone rates fell prior to the opening of a second international gateway. Two licenses were issued by GoS to operate mobile-phone technology based on the Global System for Mobile Communication ("GSM") technology. Visible changes could be seen in the behaviour of the two existing operators in Samoa as a result of competition. [4], [7], [6], [3], [13], [14]. Arguably, Digicel faced no real competition following the privatisation of SamoaTel in March 2011, claiming a significant share of the customer base through the efficient installation of cell towers [10]. Less than two years after the introduction of competition there was a marked increase across the sector.

Prior to this, Samoa had individual sectors address competition under different legislative instruments, namely Part 6 of the Telecommunications Act 2005. The fragmented national telecommunications frameworks may not itself precipitate sudden governance changes. However, it is expected, to be framed around policy regulations and laws and its subsequent responses are anticipated to be linked to competition of newly introduced international telecommunications providers to the telecommunications sector. It is here that considerable work remains to be done in mainstreaming both competition and telecommunications laws, policies and regulations into one coherent telecommunications framework.

Despite the historical context, the emergent themes emanating from the majority of our surveyed research participants support the need for stronger legislative and regulatory compliance $(50 \%)$ equally alongside fair competition (50\%) in terms of what they would like to see result in the telecommunications sector since the enactment of the new Act (ref. Table II). Higher product quality was the highest prioritised area identified for improving competition at sector, ministry and divisional levels. Our interview data indicate a diversity of opinion confirming that the telecommunications framework adequately supports full competition whilst identifying the two strong players, Digicel and Bluesky (Digicel executive, interview survey, $25^{\text {th }}$ May, 2018). Another informant explains that removing monopolies is crucial to support full competition, the universal access policy and the role of the Office of the Regulator in monitoring fair practice in the telecommunications sector (Academic/Consultant, interview survey, $21^{\text {st }}$ May, 2018 and personal communication, $24^{\text {th }}$ May, 2018) (ref. Table III).

TABLE II. PRELIMINARY FINDINGS FROM SURVEY PARTICIPANTS EMERGING TRENDS $^{\mathrm{a}}$

\begin{tabular}{|c|c|}
\hline \multicolumn{2}{|c|}{$\begin{array}{l}\text { A. What are your highest priorities for improving competition at sector, } \\
\text { ministry and divisional levels? }\end{array}$} \\
\hline Competitive pricing plans & $33.33 \%$ \\
\hline Greater product variety & $33.33 \%$ \\
\hline Higher product quality & $50.00 \%$ \\
\hline Greater innovation & $33.33 \%$ \\
\hline
\end{tabular}

\begin{tabular}{|c|c|}
\hline All of the above & $33.33 \%$ \\
\hline Other & $16.67 \%$ \\
\hline \multicolumn{2}{|c|}{$\begin{array}{l}\text { B. What would you like to see result in the telecommunications sector } \\
\text { since the enactment of the Competition and Consumer Act 2016? }\end{array}$} \\
\hline Lower probability of bid rigging & $16.67 \%$ \\
\hline Less abuse of market power & $16.67 \%$ \\
\hline Stronger legislative and regulatory compliance & $50.00 \%$ \\
\hline Fair competition & $50.00 \%$ \\
\hline All of the above & $33.33 \%$ \\
\hline Lower probability of bid rigging & $16.67 \%$ \\
\hline \multicolumn{2}{|c|}{$\begin{array}{l}\text { C. What are the issues or problems or weaknesses relating to } \\
\text { competition in the telecommunications sector? }\end{array}$} \\
\hline $\begin{array}{l}\text { Inadequate competition law framework (i.e., competition } \\
\text { rules, policies, laws) }\end{array}$ & $16.67 \%$ \\
\hline $\begin{array}{l}\text { Inadequate telecommunications legislative and regulatory } \\
\text { framework }\end{array}$ & $33.33 \%$ \\
\hline $\begin{array}{l}\text { Lack of qualified personnel to develop, administer and } \\
\text { regulate competition in the telecommunications sector }\end{array}$ & $66.67 \%$ \\
\hline All of the above & $50.00 \%$ \\
\hline \multicolumn{2}{|c|}{$\begin{array}{l}\text { D. What particular aspects of the regulatory regime encourage } \\
\text { competition? }\end{array}$} \\
\hline $\begin{array}{l}\text { The independent regulatory role of the Office of the } \\
\text { Regulator }\end{array}$ & $33.33 \%$ \\
\hline $\begin{array}{l}\text { Mandatory legislative and regulatory compliance } \\
\text { requirements }\end{array}$ & $33.33 \%$ \\
\hline Good faith & $16.67 \%$ \\
\hline $\begin{array}{c}\text { Competitive price plans and a range of options to the } \\
\text { consumers to ensure the quality of goods and services } \\
\text { remains high }\end{array}$ & $33.33 \%$ \\
\hline Incentives to innovate, invest and operate efficiently & $33.33 \%$ \\
\hline All of the above & $33.33 \%$ \\
\hline \multicolumn{2}{|c|}{$\begin{array}{l}\text { E. What particular aspects of the regulatory regime impede your } \\
\text { organisations ability to be competitive? }\end{array}$} \\
\hline $\begin{array}{l}\text { Inadequate incentives to innovate, invest and operate } \\
\text { efficiently }\end{array}$ & $83.33 \%$ \\
\hline $\begin{array}{c}\text { Inadequate legislative and regulatory compliance } \\
\text { requirements }\end{array}$ & $50.00 \%$ \\
\hline Lack of strategic leadership and direction & $33.33 \%$ \\
\hline Lack of qualified personnel or technical capacity & $50.00 \%$ \\
\hline \multicolumn{2}{|l|}{ F. What do you perceive the role of the regulator to be? } \\
\hline $\begin{array}{l}\text { To advise the Minister for the Ministry of Communications } \\
\text { and Information Technology on policy for the } \\
\text { telecommunications sector }\end{array}$ & $16.67 \%$ \\
\hline $\begin{array}{l}\text { To implement the legal and regulatory framework for the } \\
\text { telecommunications sector }\end{array}$ & $33.33 \%$ \\
\hline $\begin{array}{l}\text { To institute and maintain appropriate measures for the } \\
\text { purpose of preventing dominant telecom service providers } \\
\text { from engaging in anticompetitive practices }\end{array}$ & $100.00 \%$ \\
\hline
\end{tabular}

$$
\text { a. Source: } 8 \text { Survey Participants }
$$

TABLE III. EMERGING THEMES FROM INTERVIEW PARTICIPANTS

\begin{tabular}{|l|}
\hline \multicolumn{1}{|c|}{ EMERGENT THEMES $^{\text {a }}$} \\
\hline $\begin{array}{l}\text { A. How does the current telecommunications legislative and regulatory } \\
\text { framework facilitate the provision of different services over different } \\
\text { platforms? }\end{array}$ \\
\hline - Opened up competition in mobile markets through deregulation, \\
removing monopolies, universal access legislation, interconnection \\
agreements \\
Facilitates interconnection, numbering, spectrum, universal services \\
over different platforms including technology neutrality \\
\hline $\begin{array}{l}\text { B. How does the Telecommunications framework support full } \\
\text { competition? }\end{array}$ \\
\hline - Heavy regulation by two dominant providers \\
- Removing monopolies \\
- The Office of the Regulator monitors fair practice \\
\hline
\end{tabular}




\section{Universal Access Policy}

Support fulls competition

\section{a. Source: 3 Informants}

\section{Competition law enforcement}

The historical background of competition law and enforcement in Western industrialised countries is different from that of Pacific countries. Prior to the development of a legal and regulatory framework for competition, whether it is adopted on account of domestic or foreign pressure, should be considered [15]: 137]. If adopted in the absence of such pressure, it suggests a high probability that enforcement against large monopolies should be vigorous as the experience of Korea has shown. In 1980, the Monopoly Regulation and Fair Trade Act was Korea's first comprehensive competition law was enacted largely in response to resolve the economic conglomerate issue created by a few large monopolies known as the Chaebo [15]. Similarly, the Radisson Accord endorsed by the Government of Fiji on 20 November 2007 achieved its first objective in Fiji to end monopoly rights in the telecommunications market. By developing the legal arrangements and responsibilities as a result of granting 15 year non-exclusive licences to all providers [7].

The adoption of competition law offers numerous advantages to emerging economies. Some critics argue that a high degree of political intervention and a lack of due process in enforcement are the major factors contributing to the potential failures in the enforcement of competition law in developing countries [16]: 605-6]. The mere existence of competition law does not confirm the establishment of an effective mechanism of enforcement [15]: 153]. Williams [17] argues that competition authorities will experience difficulty in competition law enforcement due to a lack of investigation skills, corruption, low levels of economic development, inefficient institutional systems and economic concentration. If this situation exists, networking with similar jurisdictions would be useful in the facilitation and exchange of knowledge in furtherance of building a common philosophy or framework of competition law enforcement [15]: 4, 153]. But to enforce the competition law effectively in a developing country setting, an appropriate regulatory framework needs to be put in place in order to support the process of change [18]: 304]. Moreover, to sustain this economic growth, however, it must be regulated by a complementary and robust legal and regulatory framework to ensure fair competition, transparency of competition authorities and procedural fairness in enforcement proceedings [5]. The relationship between competition law and economic growth is controversial in economic theory, despite the many studies investigating the impact of competition law on country performance, such as productivity growth and price stability [18]: 301]. Ofa [1]:2] further suggests that early signs demonstrate a positive relationship between telecommunications reform (i.e., the introduction of competition policy, privatisation policy and the establishment of an Independent Regulator) and sector performance in the SIDS, noting that regulatory capture undermines the credibility of such reforms.
However, competition legislation alone does not necessarily lead to more competitive markets. For example, when the United States first enforced competition law in the twenty first century, it initially lacked adequate personnel experienced in the application of this type of law [18]: 306]. This argument points out that competition law is not a standalone regulatory tool, and co-exists in conjunction with a wider vehicle of public policies in pursuit of economic growth. Its impact is determined by competition culture, as shaped by the prevailing socioeconomic ideology and institutional framework.

Without a supporting framework to ensure effective enforcement, competition legislation itself is neither an impediment or accessory to market competition and economic growth [18]: 305]. Our preliminary findings indicate our informants had different expectations about the legislative and regulatory context and they offered a range of opinions about the best approach according to the Samoan telecommunications context. The role of the Office of the Regulator was evaluated, with survey participants noting that a range of issues relevant to issues impeding competition in the telecommunications sector, lay outside of their jurisdiction, therefore, impeding its function (ref. Table II). When Digicel engaged in litigation, challenging decisions from the Office of the regulator, in response the GoS was not equipped with the adequate resources or technical capacity to counteract this litigious strategy. This finding was corroborated by the majority of our surveyed participants who identified the lack of qualified personnel to develop, administer and regulate competition in the telecommunications sector, equally above the inadequate competition law framework and inadequate telecommunications legislative and regulatory framework, as noted issues relating to competition in the telecommunications sector (ref. Table II). In response, the GoS amended the Telecommunications Act in 2008 mandating the use of a Telecommunications tribunal to strategically support GoS in managing its expenditure.

The majority of our surveyed participants acknowledge the role of the Office of the Regulator as instituting and maintaining the appropriate measures for the purpose of preventing dominant telecom service providers from engaging in anti-competitive practice (ref. Table II). Part VI, Competition Policy, (sections 25, 28-31) of the Telecommunications Act (2005) incorporates an anticompetitive provision. Moreover, sections 3(f) and (l) provides that one of the objectives of the Telecommunications Act (2005) is to: establish a framework for the control of anti-competitive conduct in the telecommunication sector; and to institute and maintain appropriate measures for the purpose of preventing dominant telecommunications service providers from engaging in or continuing anti-competitive practices. Also, under Part 3 (Competition Rules), section 30 of the Competition and Consumer Act (2016). However, the same cohort also indicated a greater need for legal and regulatory policies that are required to increase competition in the market and reduce anti-competitive unfair trading (ref. Table II). Similarly, our interviewed informants note the need for updated policies (Internet and Email, Broadband, National ICT, Communications sector) and laws including the Telecommunications Act (ref. Table III). 
It is important to note that regulations and policies embedded in law is not adequately achievable in practice due to the vulnerable characteristics of being part of the Pacific SIDs context, whilst placing the current telecommunications regulatory and legislative framework under considerable pressure. The attempt to establish an adequate competition regulatory and legal framework that is not heavily reliant on the islands has allegedly led to monopolies bypassing regulatory processes and engaging in anticompetitive practices.

\section{Conclusion}

This research article has provided a case study based on our preliminary findings of the telecommunications reform context in Samoa leading to the introduction of competition law. From this we can learn about how the introduction of competition in Samoa was led by the telecommunications sector with added tension from both public and private sectors. Whilst our initial evidence is preliminary it is instructive because it notes the underlying tensions that characterise the telecommunications reform process. Throughout the course of this project, we will further investigate the impact of the competition law framework. Our preliminary research data only acts as the starting point as illustrated by the ongoing debates around universal access. These findings also highlight the need to further examine other geographic, social and cultural demands in which the public and private actors operate. It could also be argued that the challenges for Samoa are not due to competition law issues per se but the tensions between our public and private actors in achieving universal access and service provision. Whilst overcoming the duopoly entrenched in the Samoan telecommunications context, the next stage involves ongoing consultation to investigate the limitations of public and private actors in the development of 'best practice' competition policies to support the competition framework.

\section{Acknowledgment}

The authors wish to thank the National University of Samoa, for their assistance, without which we would not have been able to conduct our research. We also wish to thank our research support, Muliagatele Faafofoga Auvaa Aisake Peseta-Esau, and research participants who kindly agreed to be surveyed and interviewed by the team.

\section{References}

[1] Ofa, Siope V. (2012). Telecommunications Regulatory Reform in Small Island Developing States. The Impact of the WTO's Telecommunications Commitment. Newcastle, UK: Cambridge Scholars Publishing. J. Clerk Maxwell, A Treatise on Electricity and Magnetism, 3rd ed., vol. 2. Oxford: Clarendon, 1892, pp.68-73.

[2] Telecommunication Management Group (“TMG") (2016). Legal and Institutional Framework and ICT Regulatory Toolkit. InfoDev/International Telecommunications Union ("ITU"). www.ictregulationtoolkit.org (accessed May 31, 2018).

[3] World Bank. (2015). Samoa - Third Phase of the Pacific Regional Connectivity Program Project. Washington, D.C.: World Bank Group. http://documents.worldbank.org/curated/en/813211467999714829/Sa moa-Third-Phase-of-the-Pacific-Regional-Connectivity-ProgramProject (accessed 8 March, 2018).

[4] Favaro, Edgardo., Halewood, Naomi and Rossotto, Carlo Maria. (2008). "From Monopoly to Competition: Reform of Samoa's
Telecommunications Sector", Chapter 8 in Small States, Smart Solutions: Improving Connectivity and Increasing the Effectiveness of Public Services, Favaro, E. (Editor). Washington D.C: The International Bank for Reconstruction and Development / The World Bank.

[5] Nichols, R. (2016). Competition and Preferential Trade Agreements: Observations on New Zealands Approach. International Trade and Business Law Review. 19: 269-295.

[6] Cullen, R., Chan Mow, I and Hassall, G. (2016). e-Government in the Pacific Island States: ICT Policy and implementation in Small Island Developing States. (Samoa Country Report) - Contributing background report prepared as part of a series for the "eGovernment in the Pacific Islands" book project (Springer) - Pacific Islands Public Policy Repository. School of Government, Victoria University of Wellington: Wellington. http://pipps.victoria.ac.nz/ (accessed 13 February, 2016).

[7] Ofa, Siope V. (2010). Telecommunications reform in Fiji, Samoa and Vanuatu and the credibility problem: the impact of independent regulators. Pacific Economic Bulletin, 25(1): 96 - 113.

[8] Ministry of Communications and Information Technology (MCIT) (2012). National Information and Computer Technology Policy 20122017. Government of Samoa, Apia, Samoa.

[9] Ministry of Finance (MOF). (2016). Strategy for the Development of SIDS (SDS) 2016/17 to 2019/20. Retrieved from http://www.mof.gov.ws/Services/Economy/EconomicPlanning/tabid/5 618/Default.aspx

[10] Meese, J and Chan Mow, I. (2016). The regulatory jewel of the South Pacific: Samoa's decade of telecommunications reform. Mobile Media \& Communication, 4(3): 295 - 309.

[11] He, Z.-L., Lim, K., \& Wong, P.-K. (2006). Entry and competitive dynamics in the mobile telecommuncations market. Research Policy, $35,1147-1165$.

[12] Hunter, Lawson., Gauvin, Philippe and Krause, David. (2008). Changing the presumption of when to regulate: the rationale of Canadian Telecommunications Reform. Journal of Competition Law \& Economics. 4(3): 775 - 790.

[13] Asian Development Bank (ADB) (2015). "Reform renewed: A private sector assessment for Samoa". Mandaluyong City, Philippines: Asian Development Bank. Available at: http://www.adb.org/sites/default/files/institutionaldocument/167330/r eform-renewed-psa-samoa.pdf . (accessed 18 January 2018).

[14] ADB (2016). "Pacific private sector development initiative: progress report 2014-2015". Mandaluyong City, Philippines: Asian Development Bank. Available at: http://www.adb.org/sites/default/files/institutionaldocument/178878/psdiprogress-report-2014-2015.pdf. (accessed 19 April 2018).

[15] Choi, Yo Sop. (2010). The Enforcement and Development of Korean Competition Law. World Competition. 33, 302.

[16] Nikomborirak, Deunden. (2006). The Political Economy of Competition Law: The Case of Thailand. Northwestern Journal of International Law and Business. 26: 605-606.

[17] Williams, Mark. (2013). The Political Economy of Competition Law in Asia (ed. Edward Elgar,), pp 417-419.

[18] Ma, Tay-Cheng. (2011). The effect of competition law enforcement on economic growth. Journal of Competition Law and Economics. 7(2): 301-334.

About Author (s):

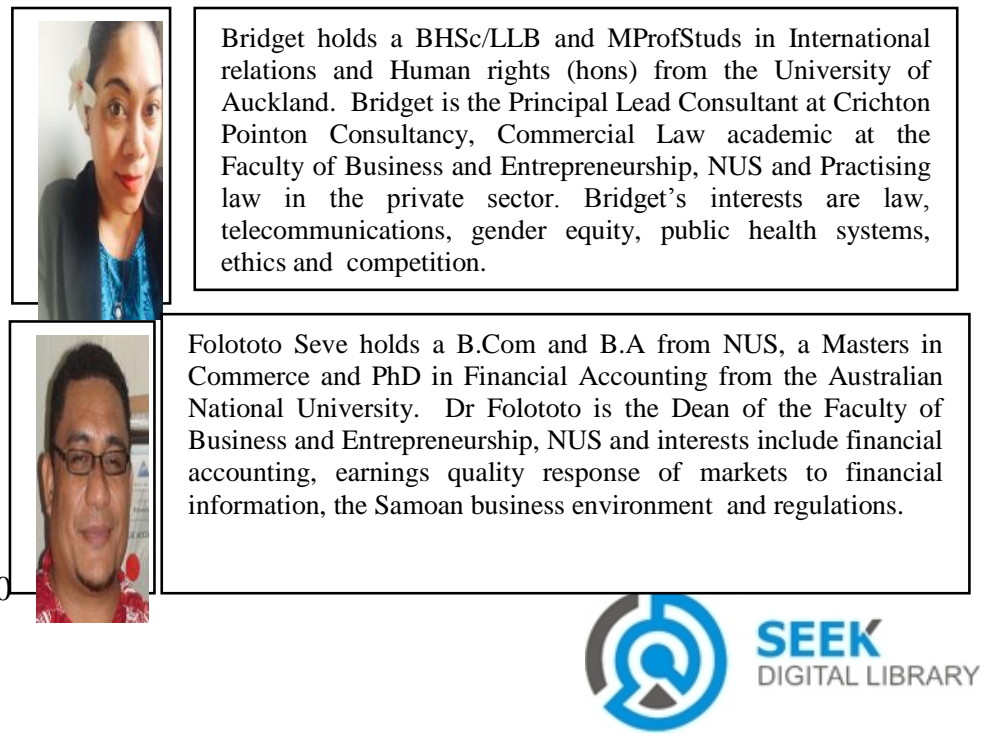

